\title{
Equations for calculating ideal body weight in patients on mechanical ventilation in adult intensive care units in Latin America: exploratory review
}

\author{
Ecuaciones para calcular el peso ideal en pacientes con ventilación mecánica en \\ unidades de cuidado intensivo adul to en Latinoamérica: revisión explora toria \\ Harold Andrés Payán Salcedo ${ }^{a, b}$ (D), José Luis Estela Zape ${ }^{a, c}$ (D), Esther C. Wilches-Luna ${ }^{b, c}$ (iD) \\ a Master Program in Biomedical Science, School of Health, Universidad del Valle. Cali, Colombia. \\ ${ }^{\mathrm{b}}$ Cardiopulmonary Physical Therapy Specialization Program, School of Human Rehabilitation, School of Health, Universidad del Valle. Cali, Colombia. \\ ' Research Group on Exercise and Cardiopulmonary Health (GIESC). Cali, Colombia.
}

Correspondence: Calle ${ }^{\mathrm{a}}$ \#36B-05, Edificio Perlaza. Segundo piso. Universidad del Valle. Cali, Colombia. E-mail: esther.wilches@correounivalle.edu.co

\section{Abstract}

What do we know about this problem?

- Ideal weight calculation requires accurate height measurement, a procedure which is not standardized in many intensive care units.

- In intensive care, the reference equation used to calculate the ideal weight is the one proposed by the Acute Respiratory Distress Syndrome Network (ARDSnet) guideline which was designed on the basis of anthropometric measurements of the United States population.

How does this study contribute? - It highlights the importance of standardizing and/or creating a protocol for measuring height in critically ill patients.

- It creates interest regarding the need to design predictive equations for calculating ideal weight based on anthropometric variables for the Latin American population.

How to cite this article

Payán Salcedo HA, Estela Zape JL, Wilches-Luna EC. Equations for calculating ideal body weight in patients on mechanical ventilation in adult intensive care units in Latin America: exploratory review. Colombian Journal of Anesthesiology. 2021;49:e949.

\section{Introduction}

Ideal body weight calculation is used in critical medicine for drug dosing and setting ventilation parameters. However, the suggested and used equations were designed on the basis of anthropometric variables that do not represent the Latin American population.

\section{Objective}

To map and present the current evidence on the equations used to calculate ideal weight in patients on mechanical ventilation in intensive care units in Latin America.

\section{Material and Methods}

Exploratory review using the Joanna Briggs Institute method conceived by Arskey / O'Malley. A search was performed in the BVS, LILLACS, REDALYC, Ovid, Coogle Scholar and Scielo databases using keywords and MeSH terms in Spanish, English, and Portuguese, with no time limitation. The results are presented in descriptive tables.

\section{Results}

Overall, 1126 studies were identified and 1120 were excluded; 6 studies were reviewed and 3 additional studies were identified through a manual search. The studies were published in Chile, Brazil, Mexico, Ecuador, and Peru. In 89\%, the ARDS Network equation was used to calculate tidal volume. Acute respiratory distress syndrome was the most reported pathology (33\%).

\section{Conclusions}

Adult intensive care units in Latin America use the equation suggested by the ARDS Network, which was designed in a population with different anthropometric characteristics.

\section{Keywords}

Respiration, artificial; critical care; tidal volume; body height; ideal body weight. 


\section{Resumen}

\section{Introducción}

El cálculo del peso ideal se utiliza en medicina crítica para dosificación de medicaciones y programación de parámetros ventilatorios; sin embargo, las ecuaciones sugeridas y usadas fueron diseñadas con variables antropométricas que no representan la población latinoamericana.

\section{Objetivo}

Mapear y presentar la evidencia actual de las ecuaciones utilizadas para calcular el peso ideal en pacientes con ventilación mecánica en unidades de cuidado intensivo de Latinoamérica.

\section{Material y métodos}

Revisión exploratoria con el método del Instituto Joanna Briggs concebido por Arskey y O’Malley. Se realizó una búsqueda en las bases de datos BVS, LILACS, Redalyc, Ovid, Coogle Scholar y SciELO con el uso de palabras clave y términos MeSH en idiomas español, inglés y portugués, sin límites de tiempo. Los resultados se presentan de forma descriptiva.

\section{Resultados}

Se identificaron 1.126 estudios, se excluyeron 1.120, se revisaron seis y se encontraron tres adicionales mediante búsqueda manual. Los estudios fueron publicados en Chile, Brasil, México, Ecuador y Perú. En el 89 \% se usó la ecuación del ARDS Network para calcular volumen corriente. El síndrome de dificultad respiratoria aguda fue la patología más informada (33\%).

\section{Conclusiones}

En las unidades de cuidado intensivo adulto de Latinoamérica se usa la ecuación sugerida por el ARDS Network diseñada en población con características antropométricas diferentes.

\section{Palabras claves}

Respiración artificial; cuidados críticos; volumen de ventilación pulmonar; estatura; peso corporal ideal.

\section{INTRODUCTION}

Ideal body weight (IBW) is similar to healthy body weight and is associated with good health condition. It is determined using equations that include anthropometric variables such as height, weight, sex and/or one or several body segments like the arm or leg; these predictive equations are used routinely by healthcare professionals (1).

Sometimes, body weight measurements - specifically in intensive care units - cannot always be made directly due to the lack of appropriate tools and the patient's condition and, therefore, subjective estimates influence the result. In such cases, equations that can be used to calculate ideal weight are needed (2). However, most equations have been designed using anthropometric variables that are not representative of the whole population spectrum, and their use overestimates ideal weight, with repercussions in critically ill patients (3).

IBW calculation is widely used in critical medicine for drug dosing, ventilator settings, glomerular filtration rate adjustments, and nutritional assessment (4). However, the equations suggested and used for the calculation originated in the United States and do not consider the very different anthropometric characteristics (weight/height) of the Latin American population.

In particular in adult intensive care units (ICUs), height measurement to estimate ideal weight is very important when it comes to determining tidal volume in patients on mechanical ventilation in order to obtain an objective, effective and preventive determination of lung ventilation and avoid and/or reduce events or complications related to inadequate tidal volume settings (5).

The Acute Respiratory Distress Syndrome Network (ARDS Network) guidelines suggest that low tidal volumes should be used in patients with acute lung injury and acute respiratory distress syndrome. Moreover, they propose an equation to calculate ideal body weight based on body height measurements. This equation, created on the basis of anthropometric measurements in the United States population, is still the gold standard for ideal weight calculation in the ICU (6).

The consequences of inadequate ideal weight estimation in critically ill patients include ventilation-related complications, considering that over or underestimations of this variable result in wrong tidal volume calculations for ventilator settings. This can 
result in lung trauma, such as volutrauma, barotrauma, atelectrauma, inflammatory cascade activation, longer mechanical ventilation, and increased ICU length of stay $(7)$.

Because body height can be influenced by environmental factors, equations for estimating ideal weight that include this anthropometric variable must be designed and validated in accordance with the characteristics of the target population. Notwithstanding, there are no known studies that have designed and proposed other equations to calculate body height in the Latin American population (8). This exploratory review maps the evidence related to the equations used to calculate ideal weight in patients on mechanical ventilation in adult ICUs in Latin America.

\section{METHODS}

This review followed the guidelines contained in the checklist for the presentation of exploratory reviews of the PRISMA-ScR declaration and was based on the Joanna Briggs Institute (JBI) method initially developed by Arksey and O'Malley (9), which was based, in turn, on the methodological guidance set forth by Peters et al. (10) that suggests: formulation of the research question, identification of relevant studies, study selection, data extraction, summary and reports of the results, and conclusions.

\section{Research question}

The following PICO question was built to guide the exploratory review: Which are the equations used to calculate ideal weight in patients on mechanical ventilation in intensive care units in Latin America? The question was designed on the basis of population, intervention, comparison and results: $P$ (Population): Adult patients on invasive mechanical ventilation. I (Intervention): Reference equations for ideal weight calculation. C (Comparison):
Not relevant. O (Outcomes): Ideal weight calculation (Figure 1). Comparison/control was not taken into consideration as it was not considered relevant during the development of the research given that there was no control group for outcome comparisons.

\section{Selection of studies}

Selected studies had to meet the following inclusion criteria: 1) Primary scientific studies, reviews, expert recommendations, lectures, guidelines or protocols published in Spanish, English and Portuguese. 2) Potentially relevant studies that answered the research question, whether published or not. 3) Studies carried out in adult Latin American population.

Studies that met the following criteria were excluded: 1) Studies that did not provide sufficient information about the equation used for calculating ideal weight. 2) Studies in which ideal weight was calculated but was used for calculations other than ventilation parameters

FIGURE 1. Inclusion criteria used on the basis of population, intervention and context.

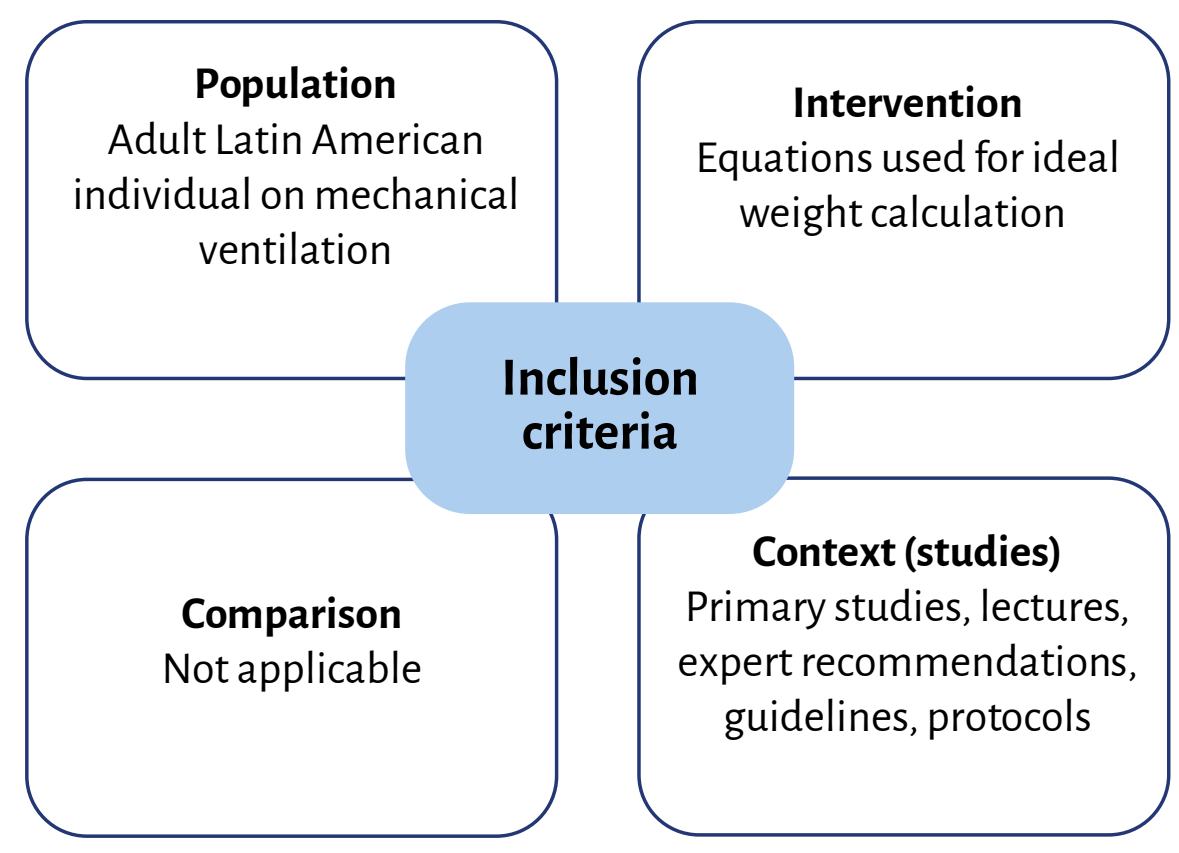

SOURCE: Authors, from Conzález-Seguel, et al. (11)

\section{Types of participants}

Selected studies described, in the methodology, the use of equations for estimating ideal weight in adult patients on mechanical ventilation in different intensive care units in Latin America.

\section{Concepts}

The relevant concepts for this review included the following:
- Intensive care units (ICUs). Intensive care consists of providing automated monitoring of multiple parameters for the management of patients with multi-organ decline, supplementary testing, basic and advanced bedside support devices and a multidisciplinary clinical team (12). This services provides care to critically ill patients with any type of disease condition (multiple trauma, surgery, respiratory disease, coronary heart disease, among others), in close collaboration with all other hospital services, in particular the emergency service (13). 
In Latin America, the first intensive care units were established in the late 1960 s and early 1970 s. It can be safely stated that intensive care units can be found in all Latin American countries, managed by intensive care physicians and equipped with sufficient technology to provide adequate management as needed (14).

- Ideal weight. It refers to a similarity with the body weight associated with good health condition. For decades, multiple equations have been used to calculate ideal weight, taking into account different body measurements such as height, body weight, ulnar length and even body mass index (15).

Ideal weight is very useful in intensive care units and, specifically, in the area of mechanical ventilation, as an essential tool for calculating tidal volume settings for objective and effective ventilation as well as for preventing ventilationrelated events such as volutrauma, barotrauma, atelectrauma, inflammatory cascade activation, length of mechanical ventilation, need for re-intubation and length of ICU stay (7).

- Body height. More sensitive than weight, this parameter is used to determine growth in length; it is critical for anthropometric assessment and essential for creating indicators involved in nutritional diagnosis, and dietary and pharmacological prescriptions $\underline{(16)}$.

- Mathematical equation. From the Latin word aequatio, it constitutes an equality in which there is at least one unknown quantity that needs to be revealed by the person solving the question. Each of the algebraic expressions that allow to discover linked data and unknown quantities through various mathematical operations are known as members.

- Mechanical ventilation (MV). Therapeutic option which, based on the understanding of the pathophysiological mechanisms of respiratory function and with the help of technological advances, offers the opportunity to provide efficient life support to critically ill patients in respiratory failure (17).

- Tidal volume (TV). Gas volume that circulates between normal inspiration and expiration. In mechanical ventilation, a volume between 6 and $8 \mathrm{~mL}$ per kilogram of ideal body weight may be programmed in patients without lung compromise (18).

-Protective ventilation. It is defined as a mechanical ventilation strategy in which low tidal volume and minimum airway pressure are used in order to prevent associated complications (17). Meta-analysis reports and randomized studies have shown that protective mechanical ventilation reduces short-term mortality (19).

\section{Identification of relevant studies}

The literature search was conducted by two physical therapists with more than 4 years of intensive care experience, advised by a biomedical librarian. The process of study identification, review, eligibility and inclusion was carried out by consensus between the researchers. Studies conducted in any Latin American country in the context of adult ICUs were selected.

\section{Search strategy}

This review used primary sources in the form original published research articles, and secondary sources in the form of existing reviews on the topic described but which included studies carried out in the Latin American population. Unpublished evidence was also included, such as results of research that met the predefined selection criteria, conducted by specialization, master's and PhD programs.

A complete search was carried out in three phases to identify published and unpublished literature on the core theme of this review: a preliminary search in the BVS, LILACS, Ovid, and SciELO databases using the keywords artificial respiration, pulmonary ventilation volume, algorithms, body size, mathematical concepts, reference values, body weight, ideal body weight in Spanish, English and Portuguese without time or language restriction. Additional keywords most frequently used in the relevant studies that met the inclusion criteria for this review were identified from the analysis of the results of the preliminary search.

A second search was conducted using all the keywords derived from the previous phase, but this time expanded to other databases (Redalyc and Coogle Scholar). In the final phase, the references listed in the articles and reviews previously selected were reviewed in depth to identify other studies and key authors to contact in order to identify primary studies or reviews not yet published or in process of publication. Time limits were not taken into account for the search and articles published in Spanish, English and Portuguese were included.

Key words sorted according to the PIO question were defined, allowing to develop a search equation with the main structured descriptors and qualifiers, and leading also to a higher degree of accuracy to localize linked terms in the articles included in the literature database of interest for the review. The general search was as follows: $P$ -Respiration, Artificial OR Tidal Volume-. I -Algorithms OR Size OR mathematical concepts OR Reference values-. O -Body Weight OR Ideal Body Weight-.

A search restriction was established as a specificity strategy with the aim of eliminating noise or the number of irrelevant studies, achieving thoroughness, and arriving at the maximum possible number of studies that contained the information relating to the research question.

To initiate the search, the concepts in the BVS and PubMed portal databases were normalized. An advanced literature search was then conducted in the databases listed in Table 1, using DeCS/MeSH terms in English, Spanish and Portuguese, and a specific search equation for each. 
The database search was completed manually with the review of the bibliographic references of the articles retrieved, in order to ensure a thorough search. This process was repeated several times in order to make sure no useful studies were overlooked.

A search of the grey literature was also conducted through the Opengrey.eu site, with no results.

\section{Data extraction}

Having completed the identification and selection phase, the researchers read the articles and prepared a descriptive table with the most relevant data. One team member removed duplicate articles and screened the remaining studies based on the information extracted from the title, the abstract and the full text, classifying it as relevant and not relevant in accordance with the pre-determined inclusion criteria. Quality control of the selection process was performed by the second researcher who assessed the excluded articles in order to ensure that no relevant information was lost. No discrepancies between researchers occurred. Table 2 describes the characteristics of the articles: author, year of publication, country of origin and context of the study, objectives, study population, sample size, methodology, variables, intervention description, and results.

\section{Presentation of the results}

The results of the review are presented in descriptive tables that show relevant aspects pertaining to the studies, including study type, type of population, sample size, country of origin of the study, equation used. Moreover, a flow diagram describing the search process and the final number of studies included is presented.

\section{RESULTS}

Overall, 1,126 studies were identified using the search equations. Following the initial selection, relevance in relation to the inclusion and exclusion criteria was assessed, resulting in 1,120 studies discarded, and 6 retained; 3 additional studies were identified through the manual search from the list of references that met the inclusion criteria. Ultimately, this review included a total number of 9 studies (Figure 2).

Of the selected studies, $56 \%$ were review articles, $22 \%$ were prospective cohort studies, $11 \%$ were clinical practice guidelines and $11 \%$ were retrospective observational studies.

The studies found were published over a 13-year period, between 2004 and 2017. In $100 \%$ of the studies, it was found that the ideal weight calculation was used for calculating tidal volume. Studies were carried out in Chile, Brazil, Mexico, Ecuador and Peru.

Various disease conditions were identified in the articles, the highest in percentage terms being acute respiratory distress syndrome (ARDS) (33.3\%), followed by acute respiratory failure syndrome (ARFS) $(22,2 \%)$, acute lung injury (11.1\%), and influenza $A \mathrm{H}_{1} \mathrm{~N}_{1}$ (11.1\%). Of the included studies, $89 \%$ used the ARDSnet equation for ideal weight calculation. Only one study, carried out in Mexico, used the 50th percentile equation of the Hispanic Health and Nutrition Examinations Survey (Table 3).

\section{DISCUSSION}

This review explored the evidence related to the use of equations for estimating ideal weight in adult patients on mechanical ventilation in Latin American ICUs.

This evidence review found that in countries like Mexico, Ecuador, Chile, Peru and Brazil the ARDSnet equation is used for calculating ideal weight in critically ill patients. This equation, created in 2000 from the ARMA study (6) was the most widely reported despite the fact that it was created on the basis of anthropometric measurements and estimations in people with very different biotypes, ethnicity and race when compared to the Latin American population, potentially giving rise to over or understimations, thus affecting their specific use.

In terms of the design and methodology of the 9 studies included in the review, $56 \%$ were reviews, $22 \%$ prospective cohort studies, and none of them described in the methodology the height measurement protocol used for calculating ideal weight with the ARDSnet.

Research studies and clinical practice guidelines indicate ideal weight calculation in patients on mechanical ventilation using the ARDSnet calculation, which includes body height and gender as variables: males: 50+0.91× (height in $\mathrm{cm}-152.4$ ) and females: $45.5+0.91 \times$ (height in $\mathrm{cm}-152.4$ ). However, no standardized methods are described for accurate and reliable measurement of body height in critically ill patients. Similar to the results found in a survey conducted by Carcía-Martínez et al. (28), it is the opinion of the authors of this review that units where no weighing tools are available (hanging scales or bed scales), continue to use visual and subjective estimates.

The studies in this review found that, in Latin America, the clinical conditions in which the ARDSnet equation was used for calculating ideal weight were ARDS (33\%), acute respiratory failure (22\%) and $\mathrm{A} \mathrm{H}_{1} \mathrm{~N}_{1}$ pneumonia $(11 \%)$, perhaps due to the fact that the ARMA study, from which the equation was derived, proposed low-volume lung ventilation ( $6 \mathrm{~mL} / \mathrm{kg} /$ ideal weight) as a strategy, showing that mortality was lower and there were fewer ventilation-related complications (6). However, although the equation requires measuring body height, none of the studies describe the technique or the standardization of the measurement protocol.

In the absence of predictive equations for calculating ideal weight in critically ill patients designed for the Latin American population, the ARDSnet equation continues to be the best option, which implies the need for accurate height measurement.

With this review, the authors highlight the importance of standardizing and/ or formalizing height measurements in critically ill patients, and the influence of the 
TABLE 1. Database-specific search strategy.

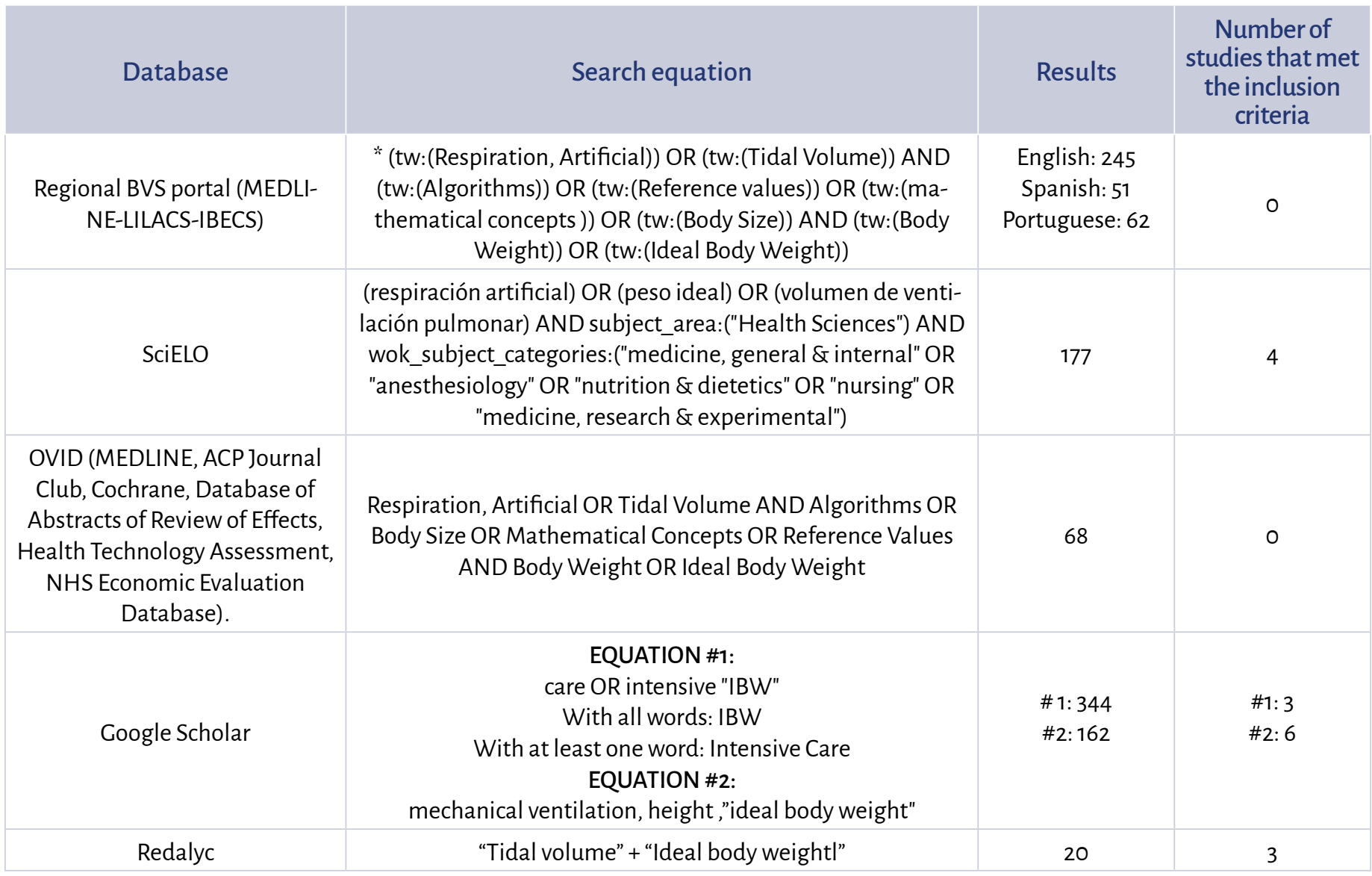

*A search was conducted with this equation in English, Spanish and Portuguese.

SOURCE: Authors.

FICURE 2. Study selection in databases.

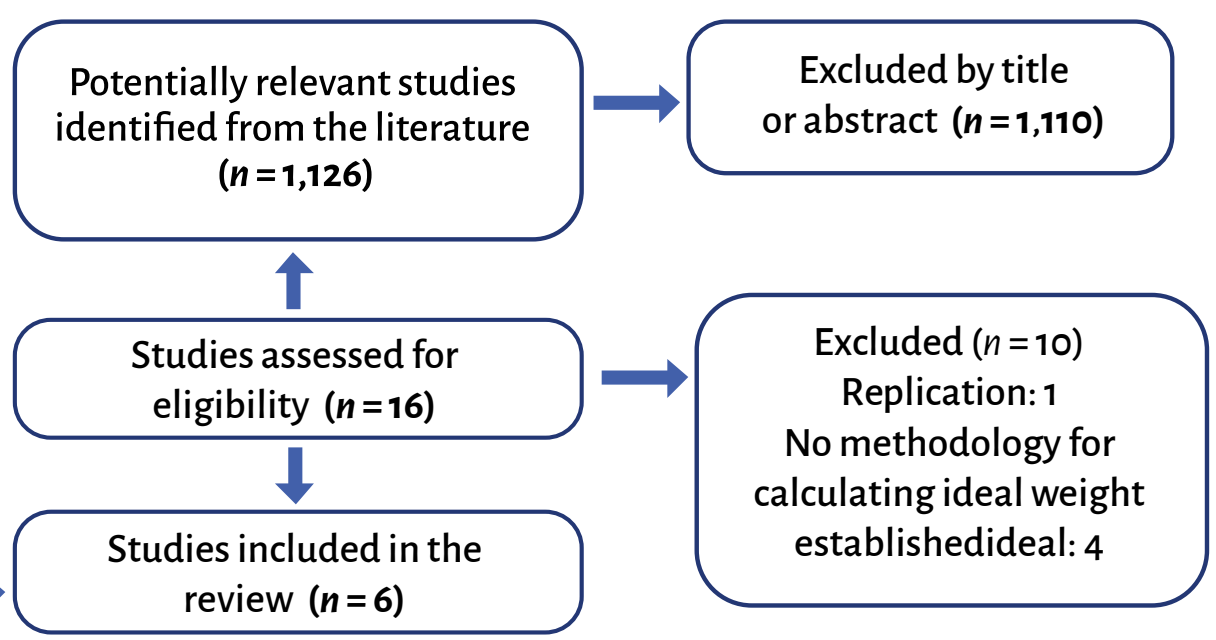

Total number of studies included in the review $(\boldsymbol{n}=\mathbf{9})$ 
TABLE 2. Summary of study findings.

\begin{tabular}{|c|c|c|c|c|c|c|}
\hline $\begin{array}{l}\text { Author, year/ } \\
\text { country }\end{array}$ & Diagnosis & $\begin{array}{l}\text { Study } \\
\text { design }\end{array}$ & $\begin{array}{l}\text { Sample } \\
\text { size }\end{array}$ & $\begin{array}{l}\text { Ideal weight } \\
\text { equation }\end{array}$ & $\begin{array}{c}\text { Purpose of } \\
\text { obtaining ideal } \\
\text { weight }\end{array}$ & Results \\
\hline $\begin{array}{l}\text { Olvera Guz- } \\
\text { mán et al., } \\
2004(20) / \\
\text { México }\end{array}$ & $\begin{array}{l}\text { Group A:ARFS } \\
\text { andGroup B: no } \\
\text { ARFSconnected } \\
\text { to MV }\end{array}$ & $\begin{array}{l}\text { Prospective } \\
\text { cohort } \\
\text { study }\end{array}$ & $\begin{array}{l}203 \\
\text { patients }\end{array}$ & $\begin{array}{l}\text { 5oth percentileof } \\
\text { the Hispanic Health } \\
\text { and Nutrition } \\
\text { Examinations Survey }\end{array}$ & TV setting & $\begin{array}{l}\text { Adequate adherence to international } \\
\text { recommendations regarding the use } \\
\text { of MV in patients with ARFS }\end{array}$ \\
\hline $\begin{array}{l}\text { Domínguez } \\
\text { Cherit et al., } \\
2009 \text { (21)/ } \\
\text { México }\end{array}$ & $\begin{array}{l}\text { Influenza } \\
\text { A H1N1 } \\
\text { connected to } \\
\text { MV }\end{array}$ & $\begin{array}{l}\text { Clinical } \\
\text { practice } \\
\text { guideline }\end{array}$ & $\mathrm{N} / \mathrm{A}$ & $\begin{array}{c}\text { M: } 50+2,3 \text { [Height } \\
\text { (inches)-60]F: } \\
45.5+2.3 \\
\text { [Height } \\
\text { (inches)-60] }\end{array}$ & TV settings & $\begin{array}{l}\text { MV strategies defined in critically ill } \\
\text { patients with Influenza } A \mathrm{H}_{1} \mathrm{~N} 1 \text { and } \\
\text { respiratory failure }\end{array}$ \\
\hline $\begin{array}{l}\text { Tominic et } \\
\text { al., } 2010(22) / \\
\text { Chile }\end{array}$ & $\begin{array}{c}\text { ARDS } \\
\text { connected to } \\
\text { MV }\end{array}$ & $\begin{array}{l}\text { Review } \\
\text { article }\end{array}$ & $\mathrm{N} / \mathrm{A}$ & $\begin{array}{l}\text { M: } 50+0,91 \times \text { (height } \\
\text { in } \mathrm{cm}-152,4 \text { ) } \\
\mathrm{F}: 45.5+0.91 \times \\
\text { (height in } \mathrm{cm}-152.4 \text { ) }\end{array}$ & $\begin{array}{l}\text { Tidal volume } \\
\text { settings in } \\
\text { patients with } \\
\text { ARDS }\end{array}$ & $\begin{array}{l}\text { Mechanical ventilation settings } \\
\text { in patients with ARDS is still } \\
\text { controversial }\end{array}$ \\
\hline $\begin{array}{l}\text { Paredes et } \\
\text { al., } 2010(23) / \\
\text { Ecuador }\end{array}$ & $\begin{array}{c}\text { ARDS } \\
\text { connected to } \\
\text { MV }\end{array}$ & $\begin{array}{l}\text { Prospective } \\
\text { cohort } \\
\text { studies }\end{array}$ & $\begin{array}{l}24 \\
\text { patients }\end{array}$ & $\begin{array}{c}\mathrm{H}: 50+0,91 \times \\
\text { (altura In cm- } \\
152,4 \text { ) } \\
\text { M:45,5+0,91× } \\
\text { (altura en cm- } \\
152,4 \text { ) }\end{array}$ & TV settings & $\begin{array}{l}\text { Over a } 2 \text {-month period, } 24 \text { patients } \\
\text { were admitted to the ICU with } \\
\text { suspected influenza } A H_{1} N_{1} \text {. All of } \\
\text { the patients presented with severe } \\
\text { hypoxemia on admission; } 100 \% \\
\text { required } M V \text {; mortality in this group } \\
\text { of patients with invasive and non- } \\
\text { invasive ventilation was } 16.6 \%\end{array}$ \\
\hline $\begin{array}{l}\text { Seiberlich et } \\
\text { al., } 2011(24) / \\
\text { Brasil }\end{array}$ & $\begin{array}{l}\text { ALI and ARDS } \\
\text { connected to } \\
\text { MV }\end{array}$ & $\begin{array}{l}\text { Review } \\
\text { article }\end{array}$ & $\mathrm{N} / \mathrm{A}$ & $\begin{array}{l}\text { M:50+0.91 × (height } \\
\text { in } \mathrm{cm}-152.4 \text { ) } \\
\text { F: } 45.5+0.91 \times \\
\text { (height in } \mathrm{cm}-152,4 \text { ) }\end{array}$ & TV settings & $\begin{array}{c}\text { Protective ventilation could } \\
\text { minimize end-expiratory stretching } \\
\text { and potential inflation/alveolar } \\
\text { collapse }\end{array}$ \\
\hline $\begin{array}{l}\text { Gutiérrez } \\
\text { Muñoz, } 2011 \\
\underline{(18) / P e r u ́ ~}\end{array}$ & $\begin{array}{c}\text { ARFS } \\
\text { connected to } \\
\text { MV }\end{array}$ & $\begin{array}{l}\text { Review } \\
\text { article }\end{array}$ & $\mathrm{N} / \mathrm{A}$ & $\begin{array}{l}\text { M:50+0.91 × (height } \\
\text { in } \mathrm{cm}-152.4) \\
\text { F: } 45.5+0.91 \times \\
\text { (height in } \mathrm{cm}-152.4 \text { ) }\end{array}$ & $\begin{array}{l}\text { Initial settings/TV } \\
\text { change }\end{array}$ & $\begin{array}{l}\text { Detailed description of the } \\
\text { mechanical ventilator, use mode, } \\
\text { ventilation parameters, indications } \\
\text { and physiological effects }\end{array}$ \\
\hline $\begin{array}{l}\text { Bugedo et } \\
\text { al., } 2014 \underline{(25) /} \\
\text { Chile }\end{array}$ & $\begin{array}{l}\text { Brain death } \\
\text { connected to } \\
\text { MV }\end{array}$ & $\begin{array}{l}\text { Review } \\
\text { article }\end{array}$ & $\mathrm{N} / \mathrm{A}$ & $\begin{array}{l}\text { M:50+0.91 × (height } \\
\text { in } \mathrm{cm}-152.4 \text { ) } \\
\text { F: } 45,5+0.91 \times \\
\text { (height in } \mathrm{cm}-152.4 \text { ) }\end{array}$ & $\begin{array}{l}\text { TV settings in the } \\
\text { potential cadaver } \\
\text { donor }\end{array}$ & $\begin{array}{l}\text { It is essential to maintain adequate } \\
\text { perfusion, protective ventilation } \\
\text { strategy and metabolic/hormonal } \\
\text { support of the potential cadaver } \\
\text { donor }\end{array}$ \\
\hline $\begin{array}{l}\text { Rocha Rossi } \\
\text { et al., } 2014 \\
\underline{(26) / B r a s i l}\end{array}$ & $\begin{array}{c}\text { Obesity } \\
\text { connected to } \\
\text { MV }\end{array}$ & $\begin{array}{l}\text { Review } \\
\text { article }\end{array}$ & $\mathrm{N} / \mathrm{A}$ & $\begin{array}{l}\text { M:50+0.91 × (height } \\
\text { in } \mathrm{cm}-152.4) \\
\text { F: } 45.5+0.91 \times \\
\text { (height in } \mathrm{cm}-152.4 \text { ) }\end{array}$ & TV settings & $\begin{array}{l}\text { Existing data suggest protective } \\
\text { ventilation strategy with low TV, } \\
\text { recruitment maneuvers and higher } \\
\text { PEEP in obese patients during surgery. }\end{array}$ \\
\hline $\begin{array}{l}\text { Gálvez Blan- } \\
\text { co et al., } 2017 \\
\underline{(27) / M e ́ x i c o ~}\end{array}$ & $\begin{array}{l}\text { Patients } \\
\text { subjected to } \\
\text { NIMV }\end{array}$ & $\begin{array}{l}\text { Retrospective } \\
\text { observational } \\
\text { study }\end{array}$ & $\begin{array}{l}40 \\
\text { patients }\end{array}$ & $\begin{array}{l}\mathrm{H}: \text { (Height in cm- } \\
152.4) \times 0.91+50 \\
\text { M: (Height in cm- } \\
152.4) \times 0.91+45.5\end{array}$ & $\begin{array}{l}\text { TV monitoring as } \\
\text { predictor of NIMV } \\
\text { failure }\end{array}$ & $\begin{array}{c}\text { Initial TV and after } 6 \text { hours of NIMV } \\
\text { is not a predictor of failure of this } \\
\text { therapy }\end{array}$ \\
\hline
\end{tabular}

ALI: acute pulmonary injury; ARDS: acute respiratory distress syndrome; ARFS: acute respiratory failure syndrome; MV: mechanical ventilation; NIMV: non-invasive mechanical ventilation; N/A: not applicable; PEEP: positive end-expiratory pressure: TV: tidal volumen.

SOURCE: Authors. 
TABLE 3. Summary and characterization of the studies.

\begin{tabular}{|c|c|c|c|c|c|}
\hline Author & Sample & Diagnosis & Year & Equation & Country \\
\hline $\begin{array}{l}\text { Olvera Guzmán et } \\
\qquad \text { al. } \underline{(20)}\end{array}$ & $\mathrm{N} / \mathrm{A}$ & $\begin{array}{l}\text { Group A: Patients with ARFS and } \\
\text { Group B: patients without ARFS }\end{array}$ & 2004 & $\begin{array}{l}\text { 50th percentile of the Hispanic Health } \\
\text { and Nutrition Examinations Survey }\end{array}$ & México \\
\hline Domínguez et al. (21) & $\mathrm{N} / \mathrm{A}$ & Influenza A H1N1 & 2009 & ARDSnet & México \\
\hline Tominic et al. $\underline{(22)}$ & $\mathrm{N} / \mathrm{A}$ & ARDS & 2010 & ARDSnet & Chile \\
\hline Paredes et al. (23) & & 24 patients/ARDS & 2010 & ARDSnet & Ecuador \\
\hline Seiberlich et al. (24) & $\mathrm{N} / \mathrm{A}$ & $\begin{array}{l}\text { Patients without pulmonary injury, } \\
\text { patients with ALI and ARDS }\end{array}$ & 2011 & ARDSnet & Brasil \\
\hline Gutiérrez (18) & $\mathrm{N} / \mathrm{A}$ & Patients with ARFS & 2011 & ARDSnet & Perú \\
\hline Bugedo et al. (25) & $\mathrm{N} / \mathrm{A}$ & Patients with brain death & 2014 & ARDSnet & Chile \\
\hline Rocha et al. (26) & $\mathrm{N} / \mathrm{A}$ & Obese patients & 2014 & ARDSnet & Brasil \\
\hline Gálvez et al. (27) & & $\begin{array}{l}40 \text { patients/Patients with hypoxe- } \\
\text { mic ARFS }\end{array}$ & 2017 & ARDSnet & México \\
\hline
\end{tabular}

ALI: acute lung injury; ARDS: acute respiratory distress syndrome; ARFS: acute respiratory failure syndrome; N/A: not applicable.

SOURCE: Autores.

method utilized on the interpretation of the clinical outcomes; and, moreover, of creating interest regarding the design of predictive equations for the calculation of ideal weight based on anthropometric variables in the Latin American population. Future research should focus on the design and validation of equations in our population.

The strength of this review lies in the selection process guided by the Joanna Briggs Institute (JBI) tool. Difficulty searching the grey literature in an attempt at identifying relevant unpublished material was found to be a limitation.

In conclusion the equation proposed by the ARDSnet is the most widely used in adult intensive care units in Latin America for calculating ideal body weight.

\section{ACKNOWLEDGEMENTS}

\section{Author's contributions}

HAPS and JLEZ. Study planning, data collection, interpretation of the results, data analysis and initial and final drafting of the manuscript.

ECWL. Conception of the original project, study planning, interpretation of the re- sults, and drafting and approval of the final manuscript.

\section{Assistance for the study}

None declared.

\section{Funding and sponsorship}

None declared.

\section{Conflict of interest}

None declared.

\section{Presentations}

None declared.

\section{Appreciations}

None declared.

\section{REFERENCES}

1. Ramírez LE, Negrete LNL, Tijerina SA. El peso corporal saludable: Definición y cálculo en diferentes grupos de edad. Rev Salud Publica Nutr. 2012;13(4).

2. Díaz de León González E, Tamez Pérez HE, Hermosillo HG. Estimación del peso en adultos mayores a partir de medidas antropométricas del Estudio SABE. Nutr Hosp. 2011;26(5):1067-72.

3. Corbo ], Canter M, Grinberg D, Bijur P. Who should be estimating a patient's weight in the emergency department? Acad Emerg Med. 2005;12(3):262-6. doi: https://doi.org/10.1197/j.aem.2004.10.005

4. García del Moral MR, Morales Laborías ME, Fernández López I, Rodríguez Delgado E, Díaz Castellanos MA. Estimación subjetiva del peso y talla de los pacientes de UCI. Medidas poco aconsejables. Medicina Intensiva. 2013;37(1):50-2. doi: https://doi.org/10.1016/j. medin.2012.03.016.

5. Linares-Perdomo O, East DT, Browner R. Standarizing predicted body weight equations for mechanical ventilation tidal volume settings. Chest. 2013;148(6):490. 
6. ARDS NETWORK. ARDSNet Study 01, versión 3. Critical Document; 1998. p. 1-55.

7. Agency for Healthcare Research and Quality Advancing Excellence in Health. AHRQ safety program for mechanically ventilated patients low tidal volume ventilation guide for reducing ventilator-associated events in mechanically ventilated patients LTVV Guide AHRQ Safety Program for Mechanically Ventilated Patients. AHRQ [Internet]. 2017;V(16). Disponible en: https://www.ahrq.gov/sites/ default/files/wysiwyg/professionals/quality-patient-safety/hais/tools/mvp/modules/ technical/ltvv-mvpguide.pdf

8. Risk NCD, Collaboration F. A century of trends in adult human height NCD Risk Factor Collaboration (NCD-RisC). Elife. 2016;5:1-29. doi: https://doi.org/10.7554/eLife.13410

9. Arksey H, O'Malley L. Scoping studies: Towards a methodological framework. Int ] Soc Res Methodol Theory Pract. 2005;8(1):1932. doi: https://doi.org/10.1080/136455703200 $\underline{0119616}$

10. Peters MDJ, Godfrey CM, Khalil H, Mclnerney P, Parker D, Soares CB. Guidance for conducting systematic scoping reviews. Int ] Evid Based Healthc. 2015;13(3):141-6. doi: https://doi. org/10.1097/XEB.0000000000000050

11.Conzález-Seguel F, Camus-Molina A, Jasmén Sepúlveda A, Pérez Araos R, Molina Blamey ], Graf Santos ]. Settings and monitoring of mechanical ventilation during physical therapy in adult critically ill patients: Protocol for a scoping review. BM] Open. 2019;9(8). doi: https://doi.org/10.1136/bmjopen-2019-030692

12. Ochoa Parra M. Historia y evolución de la medicina crítica: de los cuidados intensivos a la terapia intensiva y cuidados críticos. Acta Colomb Cuid Intensivo. 2017;17(4):258-68. doi: http://dx.doi.org/10.1016/j.acci.2017.08.006
13. Cruz RGP. Medicina intensiva y las unidades de cuidados intensivos. Rev Med Hondur. 1992;60:49-52.

14. Celis Rodríguez ESR. Desarrollo del cuidado intensivo en Latinoamérica. Todo hosp. 2007:554(38):97-100.

15. MüllerM]. Ideal body weightor BMI: So, what's it to be? Am J Clin Nutr. 2016;103(5):1193-4. doi: https://doi.org/10.3945/ajcn.116.134221

16. Monteiro RSC, Cunha TRL, Santos MEN, Mendonça SS. Estimativa de peso, altura e índice de massa corporal em adultos e idosos americanos : revisão. Rev Ciência e Saúde. 2009;20:341-50.

17. Reina Ferragut C, López-Herce ]. Complicaciones de la ventilación mecánica. An Pediatría. 2003;59(2):160-5. doi: http://dx.doi. org/10.1016/S1695-4033(03)78741-4

18. Gutiérrez Muñoz F. Ventilación mecánica. Acta Med Per. 2011;28(2):87-104.

19. Jiménez Tortosa MR. Ventilación protectora pulmonar y mortalidad tardía en SDRA. Rev Electron anestesia. 2013;5(10):2-5. doi: https:// doi.org/10.30445/rear.v5i3.293

20. Olvera Guzmán C, González Elizalde ], Martínez Sánchez J. Adherencia a las recomendaciones en ventilación mecánica en la unidad de terapia intensiva. Rev la Asoc Mex Med Crítica y Ter Intensiva. 2004;18:5-10.

21. Domínguez Cherit G. Manejo del paciente en estado critico. Secr Salud, Mex DF [Internet]. 2009; Primera ed:1-46. Disponible en: http:// www.promocion.salud.gob.mx/dgps/descargas1/influenza/mat/Guia_de_Apoyo_para
el_Manejo_del_paciente_en_estado_critico_influenza.pdf

22. Tomicic V, Fuentealba A, Martínez E, Graf ], Batista Borges ]. Fundamentos de la ventilación mecánica en el síndrome de distrés respiratorio agudo. Med Intensiva. 2010;34(6):418-27. doi: https://doi.org/10.1016/j.medin.2009.10.005

23. Paredes G, Cevallos C. Síndrome de distrés respiratorio agudo, durante la pandemia de influenza A H1N1 2009 en Ecuador. Med Intensiva. 2010;34(5):310-7. doi: https://doi.org/10.1016/j.medin.2010.03.011

24. Seiberlich E, Santana JA, Chaves RDA, Seiberlich RC. Ventilación mecánica protectora, ¿por qué utilizarla? Rev Bras Anestesiol. 2011;61:361-5. doi: https://doi.org/10.1590/ So034-70942011000500015

25. Bugedo G, Bravo S, Romero C, Castro R. Manejo del potencial donante cadáver. Rev Med Chil. 2014;142(12):1584-93. doi: https://doi. org/10.4067/So034-98872014001200012

26. Rocha RG, Boni CLA, Boas WWV. Ventilation and difficulties related to obesity. Rev Médica Minas Cerais. 2014;24(Supl 8):11-8. doi: https://doi.org/10.5935/2238-3182.20140122

27. Gálvez BCA, Aisa ÁA, Aguirre SJS, et al. El volumen tidal como predictor temprano de falla en ventilación mecánica no invasiva en la insuficiencia respiratoria aguda hipoxémica. Med Crítica. 2017;31(4):213-7.

28. García-Martínez MA, Cherednichenko T, Hidalgo Encinas Y, Catalá Espinosa Al, Arrascaeta Llanes A, Acosta Escribano JA. Calidad de la medición antropométrica en las Unidades de Medicina Intensiva españolas (Estudio CAMIES). Med Intensiva. 2018;42(6):329-36. doi: https://doi.org/10.1016/j.medin.2017.09.008 